\title{
Teresa Korbutowicz
}

Uniwersytet Wrocławski

DOI: $10.19195 / 1733-5779.19 .14$

\section{Jerzy Chodorowski - teoretyk ekonomii i historyk myśli ekonomicznej}

JEL classification: B31, B41, F15

Słowa kluczowe: definicje ekonomiczne, teoria i doktryna integracji gospodarczej, systemy ekonomiczne, Grossraunwirtschaft

Keywords: definitions of economic theory and doctrine of economic integration, economic systems, Grossraunwirtschaft

Abstrakt: Jerzy Chodorowski był uczonym zajmującym się zagadnieniami z zakresu teorii ekonomii, doktryn ekonomicznych, europejskiej integracji gospodarczej i metodologii ekonomii. Pozostawił bogaty dorobek naukowy: monografie, liczne artykuły, thumaczenia tekstów ekonomicznych, esejów G.K. Chestertona oraz recenzje prac ekonomicznych, historyczno-filozoficznych, z etyki gospodarczej i niemieckiej doktryny gospodarki wielkiego obszaru. J. Chodorowski odznaczał się niezwykłą pracowitością, rzetelnością i dociekliwością naukową.

\section{Jerzy Chodorowski - economics theorist and historian of economic thought}

Abstract: Jerzy Chodorowski was a scientist dealing with the issues of theory of economics, economic doctrines, European economic integration and methodology of economics. He left rich scientific achievements: monographs, numerous articles, translations of economic texts and essays by G.K. Chesterton as well as reviews of the works in the field of economics, history and philosophy, business ethics and the doctrine of the German economy of a great area. J. Chodorowski featured extraordinary diligence, honesty and scientific inquisitiveness.

\section{Wstęp}

W cyklu wystaw poświęconych uczonym Wydziału Prawa, Administracji i Ekonomii Uniwersytetu Wrocławskiego zostały zaprezentowane sylwetki 
Jerzego Chodorowskiego i Wiesława Sameckiego. Mottem wystawy były słowa Marcusa Tuliusa Cicero: Przyjaźn może istnieć tylko wśród ludzi prawych. Słowa te odnoszą się do dwóch osób - Jerzego Chodorowskiego (1920-2011) i Wiesława Sameckiego (1927-2007). Cecha prawości, obok rzetelności, sumienności, dociekliwości i wytrwałości w poszukiwaniu prawdy, wyraźnie widoczna jest w pracach naukowych obu uczonych. W dorobku J. Chodorowskiego znajdują się monografie i artykuły z zakresu metodologii ekonomii, doktryn ekonomicznych, doktryny i ideologii europejskiej integracji gospodarczej, teorii ekonomii oraz recenzje i tłumaczenia tekstów. Wśród przekładów przeważają prace ekonomiczne P. Sraffa, Eugena V. Schneidera, Roberta M. Solowa, ale są też prace z innych niż ekonomia dziedzin, jak eseje Gilberta K. Chestertona, artykuł ks. A. Głażewskiego' ${ }^{1}$. Różnorodnością tematyki zaskakują także recenzowane publikacje, począwszy od prac ekonomicznych np. Richarda L. Meiera, C.F. Cartera, B.R. Williamsa, po prace z dziedziny historii filozofii H. Waśkiewicza, etyki gospodarczej ks. J. Majki².

W artykule podjęto próbę określenia zakresu prac badawczych J. Chodorowskiego, zwrócenia uwagi na jego dorobek, warsztat badawczy i różnorodność zainteresowań naukowych. $\mathrm{Z}$ bogatej spuścizny uczonego przedstawione zostały najważniejsze monografie opublikowane w latach 1972-2011 z pominięciem tłumaczeń, recenzji i licznych artykułów z zakresu teorii integracji gospodarczej, historii myśli ekonomicznej, metodologii ekonomii i ogólnej teorii ekonomii.

\section{Metodologia ekonomii w pracach Jerzego Chodorowskiego}

Pierwsze publikacje J. Chodorowskiego dotyczyły metodologii ekonomii, a ściślej definicji ekonomicznych w systemach ekonomicznych. Zagadnienia te były przedmiotem rozprawy doktorskiej, opublikowanej w 1974 r., jako monografia pt. Definicje w systemach ekonomicznych. Rozstrzygnięto w niej trzy kwestie 1) roli, jaką spełniają definicje w systemach ekonomicznych, 2) wymogów poprawności definicji ekonomicznych i 3) możliwości ujednolicenia odmiennych

1 P. Sraffa, Produkcja towarów za pomoca towarów, przeł. J. Chodorowski, Warszawa 1965; E.V. Schneider, Biurokracja przemysłowa, [w:] System spoteczny przedsiębiorstwa, Warszawa 1966, s. 37-66; R.M. Solow, Teoria kapitału i stopa przychodu, Warszawa 1967; G.K. Chesterton, Ogólnie biorąc... 12 szkiców na tematy aktualne, Poznań 1998; Ks. A. Głażewski, Muzyka kryształów, roślin $i$ istot ludzkich, archiwum Jerzego Chodorowskiego.

2 J. Chodorowski, [rec.], R.L. Meier, Science and Economic Development, New York 1956, „Kwartalnik Historii Nauki i Techniki” 1961, nr 1, s. 143-145; J. Chodorowski (rec.), C.F. Carter, B.R. Williams, Industry and Technical Progress, London 1957, „Kwartalnik Historii Nauki i Techniki" 1961, nr 1, s. 145; J. Chodorowski (rec.), H. Waśkiewicz, Historia filozofii prawa. Filozofia praw. Historia prawa starożytnego świata pogańskiego, cz. I, Lublin 1961, „Eos” 1961, vol. 51, z. 2, s. 384-386; J. Chodorowski, (rec.), Ks. J. Majka, Etyka życia gospodarczego, Warszawa 1980, „Zeszyty Naukowe KUL” 1982, nr 1, s. 84-89. 
definicji jednego terminu ekonomicznego ${ }^{3}$. W pracach metodologicznych z zakresu ekonomii rzadko poruszany jest problem definicji ekonomicznych (poza R.T. Malthusem, J.N. Keynesem ojcem, F. Machlupem), a jeśli już to tylko fragmentarycznie i z naciskiem na semantykę terminologii ekonomicznej, a nie na stronę logiczną zagadnienia. J. Chodorowski sformułował wymogi poprawnej definicji ekonomicznej. Jeden z nich polega na powiązaniu poszczególnych definicji ekonomicznych z definicją całego systemu ekonomicznego, drugi wymaga, aby definicje podawały opis operacji pozwalającej stwierdzić, czy jakaś rzecz pod nią nie podpada (wymóg operacyjności). Warunek ten muszą spełniać definicje pojęć nadrzędnych, czyli takich, które nie odtwarzają niczego z otaczającej nas rzeczywistości, a są jedynie myślowymi narzędziami analizy ekonomicznej, np. pojęcie indeksu cen. Definicje ekonomiczne pojęć odtwórczych, tzn. takich, które są obrazem fragmentów rzeczywistości (np. pojęcie towaru, kosztów), powinny podawać jedynie opis obserwowanego stanu rzeczy (wymóg operatywności) ${ }^{4}$. Ujednolicenie terminologii ekonomicznej i poprawność formułowania definicji mogą się przyczynić do ułatwienia dyskusji teoretycznych ekonomistów i uniknięcia w ten sposób jałowych sporów, jak i do usprawnienia procesu dydaktycznego.

W monografii omówionych zostało przeszło 400 definicji ekonomicznych. Rozdział o rozwoju definicji praw ekonomicznych w różnych szkołach lub modelach ekonomicznych został opracowany tak sumiennie i wyczerpująco, że stanowi swego rodzaju małe monografie z zakresu historii myśli ekonomicznej. Na walory tej pracy naukowej i jej pionierski charakter zwrócili uwagę w swoich recenzjach wydawniczych Lesław Adam i Tadeusz Kubiński ${ }^{5}$. Inny recenzent, Bronisław Minc, przyznając, że jest to jedna z nielicznych prac z zakresu metodologii ekonomii, zarzucał zbyt wąskie wykorzystanie poglądów K. Marksa i F. Engelsa co do używania definicji w teorii ekonomii politycznej. Twierdził ponadto, że niekiedy jest zbędne formułowanie takich definicji, a nawet szkodliwe dla analizy ekonomicznej ${ }^{6}$.

Problem definiowania pojęć ekonomicznych pozostaje nadal aktualny. W Polsce po dominacji ekonomii marksistowskiej szczególnie ważne stało się precyzyjne i jasne formułowanie definicji stosowanych terminów. W publikacjach ekonomicznych spotyka się określenia, które są nadużywane i niejasne. Takim wyrazem jest transformacja (lub okres transformacji, system transformacyjny), który, jak

3 J. Chodorowski, Definicje w systemach ekonomicznych, „Prace Wrocławskiego Towarzystwa Naukowego. Seria A” 1974, nr 163, s. 15.

${ }^{4}$ Zob. szerzej ibidem, s. $144 \mathrm{n}$.

5 Recenzje wydawnicze prof. L. Adama z 17 listopada 1972 r. i prof. T. Kubińskiego z 20 grudnia 1973 r. w archiwum Jerzego Chodorowskiego.

${ }^{6}$ Recenzja wydawnicza prof. B. Minca z 21 sierpnia 1967 r., s. 2-3, w archiwum Jerzego Chodorowskiego. 
zauważa Ludwik Skiba, jest używany „często w sposób bezrefleksyjny i błędny”7 na określenie okresu przejściowego, bez podania jego definicji. Na kwestie poprawności językowej i sprawność posługiwania się językiem (narzędziem pracy uczonego) zwraca uwagę Hanna G. Adamkiewicz-Drwiłło w pracy dotyczącej metodologii nauk ekonomicznych. Naruszenie zasad słowotwórstwa, jak podkreśla Autorka, „owocuje pojęciowymi neologizmami-potworkami”, a publikowane teksty ekonomiczne rażą wieloznacznością i niestarannością.

\section{Niemieckie doktryny gospodarcze}

W dorobku J. Chodorowskiego niemal równolegle do rozważań poświęconych metodologii ekonomii pojawiają się publikacje na temat europejskiej integracji gospodarczej i teorii integracji. Na początku dotyczą one jednej z instytucji ówczesnych wspólnot europejskich — Trybunału Sprawiedliwości, a następnie niemieckiej doktryny gospodarki wielkiej przestrzeni, jej prekursora (J.G. Fichtego) i charakteru doktryny, jak i niemieckiej opozycji wobec niej ${ }^{9}$. Zwieńczeniem tych dociekań jest kolejna ważna rozprawa naukowa (habilitacyjna) opublikowana w 1972 r. pt. Niemiecka doktryna gospodarki wielkiego obszaru Grossraumwirtschaft 1800$1945^{10}$. Praca ma charakter historyczno-doktrynalny i określa wyczerpująco początki i rozwój niemieckiej doktryny gospodarki wielkiego obszaru oraz jej twórców. Autor, jak sam to podkreśla we wstępie, ogranicza się wyłącznie do gospodarczych idei wielkoprzestrzennych. Monografia jest pionierskim przedstawieniem pełnej historii niemieckich koncepcji wielkoprzestrzennych w dziedzinie gospodarki i jak stwierdza w recenzji wydawniczej Franciszek Ryszka, wypełnia „w sposób wszechstronny poważną lukę... w dziedzinie historii doktryn ekonomicznych"11.

${ }^{7}$ L. Skiba, Ekonomia po dominacji marksistowskiej a przemiany ustrojowe, [w:] Ekonomia w Polsce po dominacji marksistowskiej. Studia i materiaty, red. idem, Wrocław 1998, s. 22.

${ }^{8}$ H.G. Adamkiewicz-Drwiłło, Współczesna metodologia nauk ekonomicznych, Toruń 2008, s. 479.

9 J. Chodorowski, Spory w tonie Europejskich Wspólnot Gospodarczych przed ich Trybunatem Sprawiedliwości, (1954-1965), „Przegląd Zachodni” 1967, nr 6, s. 255-291; idem, Działalność interpretacyjna Sądu wspólnot europejskich, „Ruch Prawniczy, Ekonomiczny i Społeczny” 1970, z. 2, s. 141-16; idem, Problematyka doktryny Grossraunwirtschaft, „Studia Śląskie” 1968, t. 13, s. 289-303; idem, J.G. Fichte - prekursor niemieckiej doktryny gospodarki wielkiej przestrzeni, „Przegląd Zachodni” 1969, nr 5, s. 87-108; idem, Niemiecka opozycja wobec rodzimych koncepcji gospodarki wielkiego obszaru, „Przegląd Zachodni” 1971, nr 4/5, s. 378-401.

10 J. Chodorowski, Niemiecka doktryna gospodarki wielkiego obszaru Grossraumwirtschaft 1800-1945, Wrocław 1972.

11 Recenzja prof. F. Ryszki z 1 czerwca 1971 r. i prof. G. Rysiaka z marca 1971 r. w archiwum J. Chodorowskiego. Podobna ocena pracy wyrażona została przez prof. J. Byczkowskiego w recenzji zamieszczonej w „Biuletynie Naukowym Zakładu Stosunków Międzynarodowych”, Opole 1973, nr 2/44, s. $105-108$. 
W Niemieckiej doktrynie gospodarki wielkiego obszaru Autor posłużył się dwiema metodami badawczymi, tj. metodą „medalionową" i metodą „rzeczową”. Pierwsza metoda polega na przedstawieniu po kolei poglądów każdego z badanych autorów, a metoda „rzeczowa” na określeniu powstania i rozwoju poglądów na poszczególne zagadnienia u różnych autorów. Pierwsza metoda została zastosowana do okresu predoktrynalnego, w którym idee wielkoprzestrzenne występowały w luźnej formie i pozostawały pod silnym wpływem indywidualnych autorów. Dla drugiego okresu rozwoju doktryny, kiedy już stanowiła ona jednolity system oparty na przesłankach naukowych, przyjęta została metoda „rzeczowa". Doktryna wystąpiła w dwóch wariantach — liberalnym i nazistowskim, a w każdym z nich odwoływano się do idei o takich samych nazwach, ale często o różnych treściach, stąd takie idee zostały omówione dwukrotnie ${ }^{12}$. Wartością przyjętej metody pracy jest konsekwentne i dokładne badanie u poszczególnych autorów idei filozoficznych i obserwacji wydarzeń gospodarczych, które miały wpływ na ich koncepcje wielkoprzestrzenne.

Jerzy Chodorowski wszystkie niemieckie pomysły gospodarki wielkiego obszaru sprowadza do jednego modelu integracji gospodarczej. Takie ujęcie metodologiczne pozwala dostrzec w doktrynie wielkiego obszaru niemiecką wersję integracji gospodarczej i połączyć nawet odległe koncepcje gospodarcze z procesami integracji zachodzącymi w Europie oraz wyodrębnić cechy konstytuujące pojęcie Grossraunwirtschaft. Do tych cech Autor zaliczył zwiększony obszar gospodarczy, komplementarność jego części składowych, protekcjonizm wewnętrzny i wiodącą rolę Niemiec w zintegrowanych gospodarkach europejskich.

Walory merytoryczne pracy odnoszą się nie tylko do wszystkich informacji na temat udziału wybitnych postaci ze świata filozofii, ekonomii, prawa i polityki w kształtowaniu i propagowaniu idei Grossraunwirtschaft, ale do dokonanych odkryć, co do roli niektórych z nich w rozwoju tych idei. Jednym z takich odkryć jest udział J.G. Fichtego w tworzeniu niemieckiej doktryny wielkiego obszaru. W recenzji F. Ryszka podkreśla wagę tego odkrycia, które pozwala uznać J.G. Fichtego za prekursora „,teorii o potrzebie ekspansji ekonomicznej w sensie terytorialnym"13. Nowatorskie są też rozważania J. Chodorowskiego dotyczące udziału polskiego ekonomisty Rogera Battaglii w formułowaniu idei doktrynalnych gospodarki wielkiego obszaru ${ }^{14}$, poglądów Zofii Daszyńskiej-Golińskiej na rolę Polski w niemieckiej Grossraunwirtschaft ${ }^{15}$ oraz stanowiska Naczelnego Komitetu Narodowego wobec niemieckich planów gospodarczych w Europie Środkowej ${ }^{16}$.

12 J. Chodorowski, Niemiecka doktryna ..., s. 16-17.

13 Recenzja wydawnicza prof. Franciszka Ryszki z 1 czerwca 1971 r., s. 1, archiwum Jerzego Chodorowskiego.

14 J. Chodorowski, Niemiecka doktryna ..., s. 153 n.

15 Ibidem, s. 100-101.

16 Ibidem, s. 155-156. 
W końcowej części rozprawy Autor, z właściwą sobie sumiennością, dokonał oceny walorów teoretycznych doktryny Grossraunwirtschaft z punktu widzenia nauki ekonomii. Zastosowanymi kryteriami były tezy nauki ekonomii na temat relacji między wielkością obszaru gospodarczego a racjonalnością produkcji, obniżką kosztów, stabilizacją koniunktury i dobrobytu. Ocena doktryny wielkiego obszaru gospodarczego przy użyciu tych kryteriów pozwoliła na sformułowanie dwóch stwierdzeń. Według pierwszego z nich teoretyczne podstawy tej doktryny nie znajdują pełnego potwierdzenia $\mathrm{w}$ teorii ekonomii, a zgodnie $\mathrm{z}$ drugim doktryna zawiera szereg tez, które stanowią zalążek teorii integracji i mogą być uznane za pośredni, całkowicie oryginalny wkład do teorii ekonomii. Tezy doktryny, które stanowią zalążek teorii integracji, dotyczą systematyki rodzajów, form i zasięgu integracji gospodarczej, ingerencji państwa w funkcjonowanie gospodarki wielkiego obszaru oraz problemu konkurencji. W tym ostatnim przypadku ważna jest zależność między rozmiarami obszaru gospodarczego a rozmiarem konkurencji ${ }^{17}$. Dodatkowo należy zwrócić uwagę, że dla niemieckiego wariantu integracji gospodarczej charakterystyczne jest łączenie słabo rozwiniętych gospodarczo państw z wysokorozwiniętymi gospodarkami.

Monografia poświęcona niemieckiej doktrynie wielkiego obszaru zawiera bogaty materiał faktograficzny, ma wprawdzie charakter historyczny, ale pozwala ustalić, do czego odwołują się rzecznicy regionalnej integracji gospodarczej. Sam Autor zwraca uwagę, że doktryny nie umierają i „na powojennym międzynarodowym jarmarku idei znalazły się... i niemieckie idee gospodarki wielkiego obszaru, tylko już bez ram nazistowskich i bez towarzystwa skompromitowanego terminu Grossraunwirtschaft. Rozpoczął się ich renesans w zmienionych warunkach, nowy okres ich dziejów"18.

O znaczeniu każdej publikacji i wadze poruszanych w niej problemów świadczy oddźwięk, z jakim dane opracowanie spotyka się u czytelników. Taką wskazówką mogą być recenzje, które ukazują się po wydaniu książki. W przypadku monografii o niemieckiej doktrynie wielkiego obszaru, oprócz wspomnianych już recenzji wydawniczych F. Ryszki i G. Rysiaka oraz J. Byczkowskiego, należy wymienić recenzje M. Czarnomskiego, Cz. Mojsiewicza i A. Wolf-Powęskiej ${ }^{19}$. Jak zauważył jeden z recenzentów, „Nie jest to praca łatwa w czytaniu, ale daje sporo materiału faktograficznego i może pobudzić do przemyśleń dotyczących

17 Szerzej na temat wartości doktryny z punktu widzenia teorii ekonomii zob. ibidem, s. 369-393.

18 Ibidem, s. 395.

19 M. Czarnomski (rec.), J. Chodorowski, Niemiecka doktryna gospodarki wielkiego obszaru, „Zaranie Śląskie” 1974, nr I-III, s. 153-157; C. Mojsiewicz (rec.), J. Chodorowski, Niemiecka doktryna gospodarki wielkiego obszaru, „Ruch Prawniczy, Ekonomiczny i Socjologiczny” 1974, nr I, s. 295 oraz A. Wolf-Powęska (rec.), J. Chodorowski, Niemiecka doktryna gospodarki wielkiego obszaru, „Studia Historica-Slavo-Germanica” 1975, vol. IV, s. 174-176. 
również problematyki współczesnej"20. Cz. Mojsiewicz natomiast podkreśla, że recenzowana praca jest dziełem stanowiącym ,,przykład dobrej roboty, zawiera cenną treść i może okazać dużą pomoc w studiowaniu... procesów integracyjnych... i niemcoznawczych"21.

\section{Problemy integracji europejskiej}

W kolejnych latach J. Chodorowski kontynuował badania nad zagadnieniami związanymi z europejską integracją, a ich wyniki zostały zamieszczone w wydanych monografiach i artykułach. W opublikowanych artykułach omówione zostały kryzysy walutowe i ich wpływ na integrację w ramach wspólnot europejskich, kwestie oddziaływania ochrony naturalnego środowiska człowieka na osiągane efekty w procesie integracji gospodarczej oraz psychologia międzynarodowej integracji gospodarczej, możliwości zmiany świadomości europejskiej w wyniku postępu scalania się krajów europejskich, jak i przedstawiona treść i osoba twórcy doktryny zjednoczenia Europy ${ }^{22}$. Kwestie odnoszące się do doktryny integracji, jej ideologów i zmiany świadomości ludzi uczestniczących w procesie scalania krajów europejskich były przedmiotem kolejno wydanych monografii. W porządku chronologicznym sa to: Osoba ludzka $w$ doktrynie i praktyce europejskich wspólnot gospodarczych ${ }^{23}$, Czy zmierzch państwa narodowego? ${ }^{24}$, Przynęty i pułapki $w$ europejskich traktatach integracyjnych ${ }^{25}$ oraz Rodowód ideowy Unii Europejskiej ${ }^{26}$.

Pierwsza monografia jest pracą z zakresu doktryn społeczno-politycznych, społeczno-ekonomicznych i teorii integracji. Uzupełnia lukę badawczą przez zwrócenie uwagi na człowieka w procesie integracji. W licznych publikacjach na temat integracji gospodarczej ich autorzy koncentrują się na dobrach gospodarczych (towarach i kapitale rzeczowym), kapitale finansowym lub usługach. Natomiast w pracy J. Chodorowskiego to człowiek jest przyczyną, aktorem i celem

20 J. Byczkowski, op. cit., s. 10.

21 C. Mojsiewicz, op. cit., s. 295.

22 J. Chodorowski, Wplyw kryzysów walutowych na integrację zachodnioeuropejska, „Prawo” 40, 1973, s. 155-177; idem, Wpływ ochrony naturalnego środowiska człowieka na produkcyjne efekty integracji gospodarczej, „Przegląd Prawa i Administracji” 1984, t. 18, s. 161-184; idem, Psychologia międzynarodowej integracji gospodarczej, „Przegląd Prawa i Administracji” 27, 1984, s. 179-194; idem, Świadomość europejska. Zamierzenia - rezultaty, „Przegląd Zachodni” 1985, nr 5/6, s. 1-18; Richard Coudenhove-Kalergiii jego doktryna zjednoczenia Europy, „Przegląd Zachodni” 1984, nr 1, s. 1-25.

23 J. Chodorowski, Osoba ludzka $w$ doktrynie i praktyce europejskich wspólnot gospodarczych, Poznań 1990.

24 J. Chodorowski, Czy zmierzch państwa narodowego? Poznań 1996.

25 J. Chodorowski, Przynęty i pułapki w europejskich traktatach integracyjnych, Rzeszów 2001.

26 J. Chodorowski, Rodowód ideowy Unii Europejskiej, Krzeszowice 2005. 
procesów integracyjnych, które zostały rozpoczęte przez niego i dla niego ${ }^{27}$. Autor wykazuje, że zmiany w świecie materialnym, będące następstwem integracji gospodarczej i politycznej, są jedynie narzędziami ,wywołania zmian roli i miejsca człowieka w społeczności ludzkiej, jego postawy duchowej i mentalności"28. Tezą książki jest wskazanie, że zamiarem ideologów i realizatorów europejskiej współpracy gospodarczej jest wychowanie nowego człowieka. Zjednoczenie gospodarcze i polityczne służyć ma przeobrażeniu Europejczyków przez zastąpienie ich postawy nacjocentrycznej postawą eurocentryczną. Za główny środek tego przeobrażenia uznano wzmożone migracje ludności w granicach ówczesnych wspólnot europejskich. J. Chodorowski stwierdza, że środek ten nie przyniósł spodziewanych efektów i ostateczny cel gospodarczej integracji nie został osiągnięty.

Dla wykazania prawdziwości tych twierdzeń określone zostały korzenie doktrynalne integracji Europy, odnoszące się do wychowania i wykształcenia nowego człowieka, a następnie stosowane we wspólnotach metody i środki do realizacji tego celu oraz efekty osiągnięte przy ich użyciu. Autor korzystał z prac ideologów i realizatorów integracji, ich wspomnień oraz materiałów źródłowych publikowanych przez wspólnoty europejskie, tj. aktów prawnych, raportów, sprawozdań, danych statystycznych. Projekty europejskiej integracji gospodarczej były inspirowane przez ideologów duchowego jej zjednoczenia, którzy sięgali do różnych postaci uniwersalizmu. W pracy wyróżniono uniwersalizm żydowski, rzymski, chrześcijański, niemiecki, wolnomularski i socjalistyczny. W odniesieniu do każdego z nich J. Chodorowski wskazał, które z powszechnych idei występujących w każdej z postaci uniwersalizmu mogły być użyteczne dla ideologów, „twórców-architektów", a jakie dla realizatorów zjednoczenia Europy. Do grupy ideologów, architektów i realizatorów, którzy mieli największy wpływ na kształt europejskiej integracji, Autor zaliczył R. Coudenhove-Kalergi, J. Monneta, J. Retingera, R. Schumana i K. Adenauera. Wybór ten uzasadnił prowadzonymi przez te osoby działaniami na rzecz zjednoczenia i ich dokonaniami.

Drugą część pracy stanowi opis realizacji doktryny integracji gospodarczej, przyjętych środków prawnych i pozaprawnych w celu zachęcenia ludzi do migracji wewnątrz wspólnot oraz osiągniętych wyników. W trzeciej części natomiast wyjaśnione zostały przyczyny niepowodzenia koncepcji przeobrażenia człowieka i zmiany jego świadomości. Brak powodzenia jest następstwem błędów tkwiących w samej koncepcji oraz odradzania się nacjonalizmów, np. powstanie we Francji prawicowej partii Frontu Narodowego za sprawą Jeana Marii Le Pena, konflikt między Walonami i Flamandami w Belgii.

Koncepcja przemiany duchowej człowieka, która zakładała zwiększoną ruchliwość geograficzną ludzi, nie przyniosła spodziewanych efektów. Zasadniczą tego przyczyną, jak zauważa J. Chodorowski, był tkwiący w niej podstawowy

\footnotetext{
27 J. Chodorowski, Osoba ludzka..., s. 7.

28 Ibidem, s. 8.
} 
błąd ekonomiczny. Polegał on na połączeniu w tej koncepcji dwóch sprzecznych ze sobą postulatów. Jednym z nich był postulat nasilenia wewnątrz wspólnot ruchliwości ludzi, a drugi to ujednolicenie warunków życia, w tym płac i warunków pracy na całym integrującym się obszarze. Takie ujednolicenie zmniejsza lub eliminuje bodźce skłaniające ludzi do migracji ${ }^{29}$. Odmienność warunków życia z kolei nasila przepływ osób, czego współcześnie najlepszym przykładem jest liczba migrujących do Wielkiej Brytanii Polaków.

Monografia ta miała wiele recenzji i omówień. I tak w recenzji wydawniczej Andrzej Siemianowski docenił rozległy zakres poruszanych w niej zagadnień należących do historii doktryn społeczno-politycznych, społeczno-ekonomicznych, pedagogicznych. Ponadto uznał, że praca ma do spełnienia pożyteczną rolę $\mathrm{w}$ procesie racjonalnej edukacji społeczeństwa ${ }^{30}$. Zaletą rozprawy jest przejrzystość i komunikatywność relacji i to, że skłania czytelnika do myślenia. Autor nie narzuca swoich ocen, wyjaśnień i prognoz, a jedynie dyskretnie wplata je we fragmenty pracy. Najwięcej uwagi recenzenci poświęcili przedstawionym w rozprawie postaciom uniwersalizmu i ich oddziaływaniu na kształt europejskiej integracji gospodarczej. W omówieniach książki przytaczają nawet znaczące fragmenty charakterystyczne dla danej postaci uniwersalizmu ${ }^{31}$. Potwierdzają w ten sposób wyjątkowość, oryginalność i kompletność zawartych w rozprawie zagadnień dotyczących doktryny i ideologii europejskiej integracji.

Krytyczne uwagi na temat tej monografii przedstawił w swojej recenzji Zbigniew Mazur, co niewątpliwie wynika z odmiennego postrzegania przez niego procesów integracji gospodarczej. Zarzuca on J. Chodorowskiemu, że „ruch europejski oceniany jest z pozycji stronnictwa idei narodowej, zwolennika tzw. zdrowego nacjonalizmu" ${ }^{32}$. Odmawia też prawa do innych niż pozytywne ocen zjednoczenia Europy. Przyznaje jednak, że trafnie dostrzeżone zostało wygaśnięcie entuzjazmu dla idei europejskiej i przejawy renesansu nacjonalizmu. W recenzji trudno znaleźć argumenty merytoryczne negujące twierdzenia i wnioski zawarte w pracy J. Chodorowskiego.

Doktrynalne źródła integracji gospodarczej Europy, opisane w książce Osoba ludzka znalazły rozwinięcie w monografii pt. Rodowód ideowy Unii Europejskiej, która uwzględnia dokonane postępy i zmiany w przebiegu integracji europejskiej. W tej ostatniej pracy zawarte zostały: charakterystyka ,drzewa rodowego idei, z których wyrasta i na których opiera się dzisiejsza Unia Europejska"33, analiza sześciu

29 Ibidem, s. 322 n.

30 Recenzja wydawnicza prof. A. Siemianowskiego, s. 5, archiwum Jerzego Chodorowskiego.

31 Zob. J. Puchalski, Typy uniwersalizmu światowego, „Demokracja Polska” z 16-31 grudnia 1993 r., s. 15 i obszerne omówienie A. Krzeptowskiego, Kulisy wielkiej manipulacji (na marginesie książki Jerzego Chodorowskiego), „Prawica Narodowa” wrzesień-październik 1990 r., nr 3, s. 5-8.

32 Z. Mazur (rec.), J. Chodorowski, Osoba ludzka w doktrynie i praktyce europejskich wspólnot gospodarczych, Poznań 1990, „Przegląd Zachodni” 1992, nr 1, s. 175.

33 J. Chodorowski, Rodowód ideowy Unii Europejskiej, Krzeszowice 2005, s. 10. 
postaci uniwersalizmu oraz omówienie osiągniętych rezultatów przez ideologów, ,architektów”, budowniczych i polityków UE. I właśnie ta część rozprawy jest najbardziej rozbudowana, uzupełniona nowymi faktami z uwagi na dokonujące się przekształcenia europejskiego ugrupowania integracyjnego oraz wyrażonymi wyraźnie ocenami stanu tych przeobrażeń. W końcowej części książki, podsumowującej półwiecze integracji, Autor stwierdza, że aktywność wokół świadomości narodowej i świadomości europejskiej, mimo niepowodzeń, jest kontynuowana. Motywem tych działań ,było przekonanie ideologów, budowniczych i przywódców politycznych integracji gospodarczej, że ostatecznym jej celem jest wychowanie nowego człowieka dla nowego świata" 34 , czego nie udało się dokonać. Trafność oceny stanu i przebiegu integracji w Europie potwierdzają wydarzenia ostatniego okresu, a zwłaszcza wynik referendum w Wielkiej Brytanii — tzw. Brexit — uznawany za budzenie się nacjonalizmu w UE i ,katastrofalny błąd'35.

\section{Wybitne postaci nauki ekonomii}

Oddzielne miejsce wśród publikacji naukowych J. Chodorowskiego zajmują prace poświęcone wybitnym ekonomistom i ich dorobkowi naukowemu. I tak wyczerpująco przedstawiona została osoba i dokonania naukowe Adama Smitha ${ }^{36}$ oraz jego wkład do nauki ekonomii, oraz ocalony od zapomnienia dorobek Romana Rybarskiego $^{37}$ i Wiesława Sameckiego ${ }^{38}$. A. Smithowi poświęcone zostały dwie monografie. W pierwszej z nich pt. Adam Smith (1723-1790) opisane zostało życie i osobowość A. Smitha (dominujące cechy charakteru), a następnie obserwowanie życia gospodarczego i poglądy filozoficzne jako tworzywo jego systemu ekonomicznego. W dalszej części znajduje się omówienie metod badawczych (abstrakcji, indukcji, dedukcji, konkretyzacji i weryfikacji), treści prac tworzących smithowski system ekonomiczny, recepcji i krytyki jego opracowań W różnych krajach. W ostatniej części książki Autor udziela odpowiedzi na pytanie, czy A. Smith był twórcą (ojcem) nauki ekonomii i udowadnia, że A. Smith nie stworzył nauki ekonomii, wyprzedził go Richard Cantillon. W 1755 r., czyli 21 lat przed wydaniem dzieła Badania nad natura i przyczynami bogactwa narodów została opublikowana praca pt. Ogólne rozważania nad naturalnymi prawami handlu. Stanowi ona pierwszy znany ,zespół wypowiedzi na tematy ekonomiczne

${ }^{34}$ Ibidem, s. 308.

35 N. Davis, Brexit to katastrofalny błąd, jego koszt będzie ogromny, „Tygodnik Powszechny” nr 27 z 3 lipca 2016, s. 13.

36 J. Chodorowski, Adam Smith (1723-1790), Wrocław 1980 oraz idem, Adam Smith (17231790), życie i dzieło autora „Badań nad natura i przyczynami bogactwa narodów”, Wrocław 2002.

37 J. Chodorowski, Roman Rybarski (1887-1942), Wrocław 1997.

38 J. Chodorowski, Wiesław Samecki (1927-2007). Jeden z wielu ekonomistów na śmierć zamilczonych. Zarys poglądów ekonomicznych, Krzeszowice 2011. 
spełniający wszystkie wymogi naukowe"39, czyli odrębności i systematyczności układu, uniwersalności, nomotetyczności i pozytywności systemu. Zasługą A. Smitha jest natomiast zebranie dotychczasowych wiadomości o gospodarce społecznej i ujęcie ich w spójny system naukowy. Dzieło Smitha stało się inspiracją do dalszego rozwoju nauki ekonomii i nadal „może być źródłem nowych pomysłów, ujęć nawet całych teorii"40.

Druga publikacja dotycząca osoby i dorobku A. Smitha pt. Adam Smith (17231790), życie i dzieło autora Badań nad naturą i przyczynami bogactwa narodów" uzupełnia i rozszerza wcześniejszą rozprawę. Dodatkowo J. Chodorowski zajmuje się tym, co nazwał błędami niepopełnionymi. Odnosi je do dwóch kwestii, a mianowicie modelu „człowieka ekonomicznego” i ,niewidzialnej ręki” oraz wskazuje, że Smith nie był twórcą nazwy pierwszego z terminów. W drugim przypadku Smith jest autorem idei i nazwy „niewidzialna ręka"41. Autor analizuje zarzuty stawiane obu konstrukcjom i przedstawia argumenty na ich obronę oraz wykazuje błędy krytyki. Model „człowieka ekonomicznego” jest narzędziem metodologicznym, które Smith używał jako abstrakcji „człowieka realnego”. W publicystyce ekonomicznej natomiast postaci „człowieka ekonomicznego” przypisuje się materializm, wyzysk, egoizm, krzywdę ludzką. Zarzuty te, jak wykazał J. Chodorowski, są nieprawdziwe, ale przyczyniły się do degradacji Smitha w publicystyce ekonomicznej i do nieufności wobec jego konstrukcji. Koncepcja „człowieka ekonomicznego” jest to jedynie intelektualne narzędzie badawcze, obraz neutralny wolny od oceny, a A. Smith wbrew zarzutom nie promował materializmu konsumpcyjnego, ale przestrzegał przed skutkami działania wad ludzkich wypaczających motyw korzyści osobistej ${ }^{42}$.

Druga konstrukcja — „niewidzialna ręka” wynika z odkrycia dokonanego przez Smitha, że „w warunkach wolności życie toczy się zgodnie z prawami natury"43. Spośród zarzutów stawianych autorowi Bogactwa narodów jest i ten mówiący o zawodności „niewidzialnej ręki” i konieczności korekty, tj. działań rządu lub organizacji społecznych. „Niewidzialna ręka” została określona przez A. Smitha w dwóch formach — modelowej w warunkach konkurencji doskonałej i realistycznej działającej w warunkach konkurencji niedoskonałej. Smith pełną efektywność ,niewidzialnej ręki” zakładał w modelowych warunkach. Dostrzegał działania zmierzające do ograniczenia wolności rynku i zagrożenia jego stabilności zmniejszające skuteczność „niewidzialnej ręki”, która mimo tych trudności może zapewnić dobrobyt i rozwój kraju. Co więcej, jest ona ochroną jednostki, gdyż podtrzymuje mechanizm rynkowy jako narzędzie zmniejszające nieuczci-

\footnotetext{
39 J. Chodorowski, Adam Smith..., s. 180.

40 Ibidem, s. 194.

41 J. Chodorowski, Adam Smith (1723-1790), życie..., s. 229 n.

42 Ibidem, s. 241.

43 Ibidem, s. 256.
} 
wości i nierówności ${ }^{44}$. Spory nadal toczące się nad dwoma fundamentalnymi dla dorobku naukowego A. Smitha pojęciami — „człowiek ekonomiczny” i „niewidzialna ręka" - mają znaczenia dla właściwego ich rozumienia, jak i ujawniają trudności w recepcji Smitha w każdym kraju. Rozważania nad błędami niepopełnionymi przez A. Smitha J. Chodorowski kończy pytaniem: „A może w tzw. krajach postkomunistycznych (i nie tylko) Adam Smith jeszcze nie przyszedł dlatego, że Karol Marks jeszcze nie odszedł?"45

Kolejną monografią poświęconą osobie i działalności naukowej wybitnego ekonomisty jest książka o polskim uczonym Romanie Rybarskim. Powody powstania tej publikacji, podane przez Autora we wstępie, są następujące: konieczność zrewidowania oceny dorobku R. Rybarskiego, dokonanej przez marksistowską historiografię ekonomiczną, aktualność wielu prac i myśli tego ekonomisty oraz nadzieja, że pojawią się podobne monografie dotyczące innych ekonomistów, co ułatwi opracowanie historii polskiej myśli ekonomicznej. Przedmiotem pracy jest osoba i bogaty dorobek naukowy R. Rybarskiego, który obejmuje prace z teorii ekonomii, historii doktryn, myśli ekonomicznej, skarbowości i polityki gospodarczej oraz opracowania historyczne. Postać Rybarskiego zaprezentowana została za pośrednictwem jego publikacji ze wskazaniem okresu nauki, kształtowania poglądów naukowych (stan wiedzy ekonomicznej oraz wpływy mistrzów - J. Dunajewskiego i W. Czerkawskiego), polemik i ocen oraz krytyki, a na końcu scharakteryzowana została jego osobowości. Rozbudowana została część poświęcona krytyce ze strony marksistów po II wojnie światowej. Autor w odniesieniu do każdej z dziedzin nauki, którą interesował się Rybarski, omawia i ocenia dokonania uczonego, wskazując na ich oryginalność, znaczenie dla rozwoju ekonomii, historii myśli ekonomicznej czy polityki gospodarczej.

W przypadku teorii ekonomii rozważania nad ważnymi, dla całościowego jej ujęcia, zagadnieniami zawarł Rybarski w pracach Wartość, kapitał, dochód, Teorii gospodarstwa społecznego, uzupełniającej System ekonomii politycznej. Zasługą uczonego jest włączenie do naukowego systemu ekonomii pojęcia podmiotu gospodarstwa społecznego, który to termin odnosił do człowieka gospodarującego celem zaspokojenia własnych potrzeb. Podejmuje się także obrony terminu bogactwa ekonomicznego jako „ogółu środków zaspokojenia potrzeb ludzkich, mających wartość wymienną"46. Rozważania na temat bogactwa i wartości wymiennej wyprzedziły badania i literaturę ekonomiczną, która niemal o pół wieku później zajęla się kwestiami związanymi z obliczeniami dochodu narodowego ${ }^{47}$. Nowością była teoria regresu gospodarczego, zgodnie z którą przyczyną re-

44 Jest to jeden z pięciu zarzutów podnoszonych wobec teorii niewidzialnej ręki, zob. szerzej ibidem, s. 256-276.

45 Ibidem, s. 276.

46 Cytowane za J. Chodorowskim, Roman Rybarski..., s. 81.

47 Ibidem, s. 85-86. 
gresu było naruszenie równowagi między produkcją dóbr konsumpcyjnych a produkcją dóbr produkcyjnych. Nieodnawianie przez społeczeństwo swojego kapitału lub odnawianie w niewystarczającym stopniu zmniejszy zaspokajanie potrzeb. Gospodarstwo, którego kapitał się zmniejsza, będzie musiało ograniczyć swoją aktywność gospodarczą ${ }^{48}$.

J. Chodorowski zwraca uwagę, że Rybarskiego interesowała przeszłość, teraźniejszość i przyszłość społeczno-gospodarcza i każdej z nich poświęcił swoją uwagę. Do prac historycznych należą: Gospodarka Biecza w XVI i poczatkach XVII wieku, Wielickie żupy solne w latach 1497-1594, Kredyt i lichwa w Ekonomii Samborskiej, Sprawa włościańska na Sejmie roku 1831, Rozwój życia gospodarczego i idei gospodarczych, Handel $i$ handlowa polityka Polski w XVI wieku, Skarbowość Polski w dobie rozbiorów, Skarb i pieniadz za Jana Kazimierza, Michała Korybuta i Jana III. Przeszłość gospodarcza Polski ilustrowana jest danymi liczbowymi. Treść wywodów historycznych, jak podkreśla J. Chodorowski, „wolna jest od błędu prezentyzmu w przedstawianiu obrazów historycznych i od na-

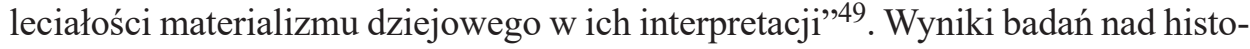
rią myśli ekonomicznej zawarte są w pracach: Idea Gospodarstwa Narodowego, System ekonomii politycznej. Oryginalnymi twierdzeniami Rybarskiego jest, że ekonomia jako nauka powstała dzięki filozofii prawa natury oraz sama koncepcja rozpatrywania myśli ekonomicznej na tle życia gospodarczego i społecznego.

W działalności naukowej Rybarskiego teraźniejszość gospodarcza jest przedstawiona w publikacjach na temat Organizacji kredytu przemystowego w Galicji i Królestwie Polskim, Bojkotów ekonomicznych w krajach obcych i Idei gospodarstwa narodowego. Książka o bojkotach ekonomicznych w swej zasadniczej części traktuje o bojkotach w walkach na tle narodowym, którymi są bojkot demonstracyjny, bojkot jako akt presji lub bojkot jako czynnik popierania rodzimej wytwórczości (przykład Czech). Bojkoty na tle narodowym podyktowane są motywami pozagospodarczymi. Pozagospodarcza motywacja działalności gospodarczej nie mieści się w czystej teorii ekonomii, ale jak podkreśla J. Chodorowski, zjawiska takie, gdy występują w dużej masie, wymagają zbadania.

Kolejnymi pracami objętymi rozważaniami w monografii J. Chodorowskiego są te dotyczące przyszłości, losów gospodarczych świata i Polski - Przyszłość gospodarcza świata, Idea gospodarstwa narodowego, przyszłość gospodarcza Polski. Przewidywania Rybarskiego na temat przyszłości gospodarki światowej odnosiły się do międzynarodowego podziału pracy i wymiany handlowej specjalizacji różnych gospodarstw narodowych, lokalizacji przemysłu, ustroju gospodarczego i integracji gospodarczej. Większość tych prognoz okazała się trafna. Dotyczy to w szczególności gospodarki planowej i integracji gospodarczej. Obraz ustroju gospodarki planowej, jaki wyłania się z prac Rybarskiego, to przymus

\footnotetext{
48 Ibidem, s. 111-112.

49 Ibidem, s. 110.
} 
państwowy zastępujący własność prywatną i biurokratyzacja gospodarki, które wykluczają przedsiębiorczość, zwiększają marnotrawstwo, prowadzą do wystąpienia defektów w podziale dochodu narodowego. W przypadku integracji gospodarczej słuszne okazały się przewidywania co do decydującej roli interesów narodowych w scalonych obszarach gospodarczych i niezanikania gospodarstw narodowych ${ }^{50}$.

$\mathrm{Z}$ dorobku Rybarskiego wydzielone zostały prace należące do polityki gospodarczej, tj. Marka polska i złoty polski, Podstawy narodowego planu gospodarczego, Polityka i gospodarstwo, Przyszlość gospodarcza Polski. Przedstawiona w nich została konstrukcja polskiej narodowej ideologii gospodarczej, która była przeciwieństwem totalizmu gospodarczego. Rybarski był rzecznikiem kapitalizacji rozumianej jako wzrastanie majątku narodowego, co miało następować przez oszczędzanie. Kapitalizacja zajmowała kluczową pozycję w jego programach gospodarczych. Pozytywne efekty może przynieść tylko kapitalizacja dobrowolna w warunkach własności prywatnej ${ }^{51}$. W rozważaniach Rybarskiego na tematy polityki ekonomicznej J. Chodorowski dostrzegł oryginalne tezy teoretyczne teorii pieniądza uzupełnienie tzw. prawo Greshama przez określenie granic jego zastosowania.

Rybarski zajmował się też finansami i ustrojem państwa (Prawnoskarbowe podstawy ustroju państw zwią kowych unii i autonomii państwowych, Nauka skarbowości, Sita i prawo, Ciężar podatków w Polsce) i twierdził, że finansowe relacje między większymi organizmami państwowymi a ich elementami składowymi dotyczą też pokrywania wspólnych wydatków. Organizm taki może mieć własne dochody, których źródła pochodzenia należy określić lub może pokrywać wspólne potrzeby z udziałów wnoszonych przez jego elementy składowe. J. Chodorowski podkreśla aktualność i trafność tych obserwacji, przywołując na potwierdzenie przyjęte w ramach EWG zasady ponoszenia kosztów utrzymania Wspólnoty ${ }^{52}$.

W Nauce skarbowości Rybarski uznał za konieczne stosowanie kryteriów etycznych oraz uwzględnienie psychologicznej strony niektórych zjawisk odnoszących się do finansów publicznych. Najważniejsze zasady moralne polityki skarbowej to powszechność opodatkowania i równość podatkowa. Zasługą Rybarskiego jest wskazanie także władz państwowych jako źródła defraudacji i upadku moralności podatkowej oraz spostrzeżenie, że podatnicy, powołując się na doznane od państwa krzywdy, wywołują defraudację o charakterze masowym, tj. przestępstwa podatkowe są traktowane w społeczeństwie jako sprytne działania ${ }^{53}$. Ostatnią częścią monografii są omówienia polemik, ocen prac Rybarskiego przez współczesnych (S. Grabskiego, S. Głąbskiego, A. Doboszyńskiego), krytyka pośmiertna oraz osobowość Rybarskiego. Przedstawione zostały polemiki z F. Bujakiem, A. Krzyżanowskim, a także quasi polemiki z tzw. austriacką szkołą

50 Ibidem, s. 177-188.

51 Zob. szerzej na temat własności prywatnej ibidem, s. 211-213.

52 Ibidem, s. 232.

$53 \mathrm{Na}$ temat oryginalności i nowatorstwa tych spostrzeżeń zob. ibidem, s. 249. 
psychologiczną i ze szkołą marksistowską. Z dużą starannością i wnikliwością J. Chodorowski ustosunkował się do stawianych Rybarskiemu zarzutów przez marksistów w powojennej Polsce. Oskarżenia te dotyczyły eklektyzmu, braku sumienności i dużej powierzchowności wywodów oraz aprobowania własności prywatnej jako podstawy rozwoju gospodarczego 54 .

Monografię kończy charakterystyka R. Rybarskiego — osobowości zharmonizowanych przeciwieństw, tj. myśliciela-działacza, teoretyka, ideologa, historyka. Analizując każdą z tych przeciwstawnych postaw, Autor poszukuje tego, co zapobiegło konfliktowi kontrastów i pozwoliło na harmonizację odmiennych predyspozycji psychicznych, talentów, uzdolnień intelektualnych. Spoiwem tym jest „,ideologia, której centralną wartość stanowi naród”, a zasada narodowa jest tą regułą organizacji społecznej, która ,wydobywa z jednostek pierwiastki o wysokiej wartości moralnej, rozwija ludzi pod względem etycznym"55.

W obszernej recenzji tej monografii Piotr Sutowicz zwraca uwagę na wyjątkowość pracy J. Chodorowskiego. Polega ona na tym, że nieliczni specjaliści chętni i gotowi są opracować historię polskiej myśli ekonomicznej i prawnej, a wyraźne są tu zaniedbania wynikłe z marksistowskiej wizji dziejów. Drugą ważną okolicznością jest omówienie wszystkich prac ekonomicznych R. Rybarskiego i, jak stwierdza recenzent, ,samo podjęcie tematu zasługiwałoby na uznanie, lecz to, że ktoś zajął się tym problemem i opracował go tak gruntownie zasługuje na podziw"s6.

Wyjątkowe miejsce wśród monografii o uczonych-ekonomistach zajmuje ostatnia opublikowana za życia Jerzego Chodorowskiego książka poświęcona jego przyjacielowi Wiesławowi Sameckiemu. Jest to bardzo osobista relacja o drodze życiowej tego uczonego, począwszy od okresu przedwojennego, przez kołchozową Batmanówkę w Kazachstanie, Junacką Szkołę Kadetów przy Armii Andersa, przez prywatną Wyższą Szkołę Handlową w powojennym Wrocławiu, po pracę naukową na Uniwersytecie Wrocławskim. W oparciu o zgromadzone dokumenty, wspomnienia i znane fakty rzetelnie przedstawione zostały wydarzenia z życia uczonego, kształtowanie się jego poglądów ekonomicznych oraz najważniejsze rozprawy naukowe. Pracami tymi są: Ryzyko i niepewność $w$ działalności przedsiębiorstwa przemystowego, Gospodarowanie za pomoca planowania, O przedmiocie i metodzie ekonomii politycznej, Centralny Okreg Przemysłowy 1936-1939: wstęna faza programu uprzemysłowienia Polski, Prolegomena do teorii ekonomii, Wprowadzenie do ekonomiki ${ }^{57}$. W odniesieniu

54 Zob. szerzej ibidem, s. 338-344.

55 Ibidem, s. 367. Zob. też J. Chodorowski, Liberat z pomówienia. W sześćdziesiąta rocznice śmierci Profesora Romana Rybarskiego 1887-1942, „Nowy Przegląd Wszechpolski” 2002, nr 9-10, s. $15-19$.

56 P. Sutowicz, J. Chodorowski, Roman Rybarski (1887-1942), Wrocław 1997, „Prawo” 250, „Życie i Myśl” 1998, nr 1, s. 103.

57 W. Samecki, Ryzyko i niepewność w działalności przedsiębiorstwa przemysłowego, Warszawa 1967; Gospodarowanie za pomoca planowania, Wrocław 1980; idem, O przedmiocie i metodzie 
do tych książek omówiony został odbiór tych prac i postawionych w nich tez ujawniony w recenzjach wydawniczych.

Obszernie wyjaśnione zostały poglądy W. Sameckiego na znaczenie matematyki i charakter jej , usług” świadczonych ekonomice. Autor monografii oceny matematyki jako nauki usługującej ekonomice, zawartej w pracach W. Sameckiego, podzielił ją na trzy kategorie, tj. uznające matematykę za albo nieprzydatną, albo niebezpieczną, albo szkodliwą. Matematyka jest nauką operującą uproszczeniami, a jej ubogi język nie może oddać skomplikowanych procesów ekonomicznych. Odtworzenie rzeczywistości gospodarczej wymaga uwzględnienia czynnika czasu, a ten czynnik nie występuje w funkcji matematycznej. Potwierdzeniem tych ocen jest ważne spostrzeżenie W. Sameckiego, że wymiana nie jest procesem wyłącznie ilościowym, gdyż konsumenci, dokonując wyboru, nie kierują się wyłącznie ilością dóbr w relacji do ceny, ale i ich jakością wobec ceny ${ }^{58}$. W rozważaniach na temat gospodarki planowej i działaniach Centralnego Planifikatora przy wyborze kierunków inwestowania W. Samecki wskazuje na niebezpieczeństwa, jakie mogą wynikać z korzystania z usług matematyki. Model matematyczny gospodarki planowej zakłada możliwość uzyskania obiektywnych wskaźników ważnych dla ustalania kierunków i rozmiarów inwestycji brutto. W gospodarce tej nie można uzyskać obiektywnych wskaźników informujących o możliwych wyborach, stąd decyzje inwestycyjne mają charakter arbitralny, a sama matematyka w sposób pośredni ma swój udział w powstawaniu szkód ekonomicznych w systemie gospodarki planowej. Formuła matematyczna może być uznana za instrument badawczy wtedy, gdy wnioski z niej wynikające zostaną zweryfikowane przez przełożenie ich na język literacki i skonfrontowane z badaniami empirycznymi życia realnego. W opinii W. Sameckiego badania empiryczne w stosunku do usługowych funkcji matematyki zajmują funkcję nadrzędną ${ }^{59}$.

Autor monografii za najważniejsze książki w dorobku W. Sameckiego uznał Gospodarowanie za pomoca planowania i Prolegomene do teorii ekonomii. Są one ze sobą ściśle powiązane, tj. bez tej pierwszej nie byłoby drugiej publikacji. Gospodarowanie za pomoca planowania jest rozprawą z dziedziny teorii gospodarki planowej i jak większość prac z teorii ekonomii pozostaje w związku z doświadczeniami rzeczywistości. W czterech kolejnych częściach pracy W. Samecki określa pojęcie gospodarki planowej, czasu w ekonomii, analizuje planowanie wielkości produkcji, planowanie struktury produkcji i planowanie dochodów. Zakończeniem

ekonomii politycznej, Wiktor Jarmulicz [pseud.], Warszawa-Wrocław 1986, Centralny Okręg Przemystowy 1936-1939: wstępna faza programu uprzemystowienia Polski, Wrocław 1998; idem, Prolegomena do teorii ekonomii, Wrocław 1998; Gospodarowanie za pomoca planowania: analiza krytyczna, Wrocław 2000; idem, Wprowadzenie do ekonomiki, Wrocław 2005.

58 Zastrzeżenia co do rozważania zagadnień ekonomicznych z ilościowego punktu widzenia przedstawił też Ludwig von Mises w pracy Ludzkie działania: traktat o ekonomii, Warszawa 2007, s. 101 .

59 Zob. szerzej J. Chodorowski, Wiesław Samecki..., s. 68-85. 
tych wywodów są wnioski, tj. charakterystyka gospodarki planowej, w tym centralizacja dyspozycji i inicjatywy ekonomicznej, która usuwa warunki występowania procesów ekonomicznych. Wnioski te rozwinięte zostały w Prolegomenie..., która z Gospodarowaniem... stanowi „dwujedność”60. Publikacja ta, podobnie, jak Wprowadzenie do ekonomiki jest też efektem nagromadzonych doświadczeń związanych z prowadzonymi wykładami na Uniwersytecie Wrocławskim. W stosunkowo krótkiej, ale pełnej treści Prolegomenie... zawarte zostały podstawowe metody badawcze ekonomiki, określenie systemu naukowego ekonomiki i charakterystyka systemów ekonomicznych. Zgromadzona wiedza o planowaniu okazała się użyteczna przy wyodrębnianiu systemów ekonomicznych — zdecentralizowanego systemu gospodarki rynkowej i scentralizowanego systemu opartego na własności państwowej lub na własności prywatnej.

W. Samecki był teoretykiem ekonomiki i w takim charakterze podjął się analizy konkretnej koncepcji rozwoju gospodarczego Polski w oparciu o udokumentowane fakty. Badaniem objęty został program przebudowy struktury gospodarczej kraju rozpoczęty w utworzonym Centralnym Okręgu Przemysłowym. Na przykładzie COP-u dokonana została empiryczna weryfikacja części ekonomicznej teorii wzrostu. Jak zwraca uwagę J. Chodorowski, celów tych nie dostrzegł recenzent pracy — historyk gospodarczy Zbigniew Landau, stawiając autorowi pracy o COP-ie zarzuty niespełnienia wymogów pracy historycznej. Nieporozumienie wynikło, jak podaje J. Chodorowski, z tego, że ,recenzent nie oceniał książki otrzymanej do recenzji, koncepcji jej autora, jego metod badawczych i otrzymanych rezultatów, lecz przedstawia własną wizję problemu, własną koncepcję jego rozwiązania i własne metody badawcze" 61 .

Cechą wyróżniającą W. Sameckiego jako człowieka i teoretyka ekonomiki jest bezkompromisowość, która, jak podkreśla Autor monografii, widoczna jest w badaniach naukowych tego uczonego i jego zachowaniu w różnych sytuacjach życiowych. W badaniach naukowych ekonomiki, tak jak to rozumiał W. Samecki, nie jest możliwy kompromis. Badania mają doprowadzić do prawdy, czyli ,zgodności abstrakcyjnego obrazu rzeczywistości gospodarczej (stworzonego przez badacza) z samą tą rzeczywistością, którą jest gospodarka rynkowa jako byt naturalny" ${ }^{\prime 2}$. Konsekwentnie też przestrzegał rozróżnienia tego co jest, od tego, co być powinno.

Znamiennym faktem jest, że tylko jedna książka W. Sameckiego doczekała się recenzji, była to praca Ryzyko i niepewność $w$ działalności przedsiębiorstwa przemysłowego ${ }^{63}$. Recenzent zwraca uwagę na pionierski charakter pracy i przyznaje, że chociaż w sposób dyskusyjny, to przyczyniła się ona do wypełnienia luki ,jaką

60 Ibidem, s. 93.

61 Ibidem, s. 122.

62 Ibidem, s. 134.

63 E. Kulwicki (rec.), W. Samecki, Ryzyko i niepewność w działalności przedsiębiorstwa przemysłowego, Warszawa 1967, „Ekonomista” 1968, nr 3, s. 785-789. 
stanowił problem niepewności i ryzyka w gospodarce planowej”64. Nie zgadza się jednak z wnioskami końcowymi, które sformułowane zostały w oparciu o przeprowadzone badania w wybranych przedsiębiorstwach przemysłu lekkiego. W. Samecki stwierdził, że w działalności przedsiębiorstw istnieje jedynie niepewność, co wynika z badanej rzeczywistości. Pozostałe publikacje ważne dla teorii ekonomiki nie doczekały się oceny ze strony ekonomistów-teoretyków. Autor monografii stawia tezę, że jest to świadome zamilczenie W. Sameckiego na śmierć przez krąg osób wyznających socjalistyczny pogląd na świat. Jednocześnie stawia pytania o przyczyny takiego stanu rzeczy i sam podaje, że wymagane jest rozpoczęcie „niełatwych, długich i pracowitych badań” ${ }^{65}$ dla uzyskania odpowiedzi na postawione pytania.

\section{Uwagi końcowe}

Prace naukowe Jerzego Chodorowskiego nie pozostawiają czytelników obojętnymi na poruszane w nich zagadnienia. Dostrzeżenie danych problemów, sposób ich przedstawienia, czy wskazanie skutków, jakie wywołują określone zjawiska lub działania, może budzić sprzeciw, podziw lub aprobatę. O różnych reakcjach mogą świadczyć opinie zawarte w przytoczonych recenzjach. Nie budzi natomiast wątpliwości rzetelność, konsekwencja i wytrwałość w poszukiwaniu prawdy oraz niezwykła pracowitość Autora. Dodatkową cechą Jerzego Chodorowskiego - uczonego - była zdolność dostrzegania $\mathrm{z}$ wyprzedzeniem zjawisk i procesów zachodzących w rzeczywistości gospodarczej i swoista ,intuicja naukowa”.

Przedstawione w artykule wybrane monografie uzupełniają liczne publikacje dotyczące doktryny europejskiej integracji (gospodarczej i politycznej), przebiegu tej integracji i zagrożenia, jakie z niej wynikają, oraz teorii ekonomii, doktryn ekonomicznych, globalizmu czy wspomnień o prof. Wincentym Stysiu ${ }^{66}$. Większość prac jest też efektem doświadczeń zgromadzonych w związku z prowadzonymi na Uniwersytecie Wrocławskim wykładami i seminariami z historii myśli ekonomicznej, doktryn ekonomicznych, teorii integracji gospodarczej i ekonomii.

$\mathrm{Z}$ monografii poświęconych uczonym-ekonomistom przemawiają do nas żywe osoby, które poznajemy jako ludzi o określonych cechach, poglądach, postawach oraz dorobku naukowym. J. Chodorowski w dyskretny sposób wskazuje na związki między osobowością uczonego i jego twórczością naukową. Można być pewnym, że wszystko to, co napisał o każdym uczonym, zostało rzetelnie i uczciwie zbadane oraz udokumentowane. W ostatniej monografii, tej

64 Ibidem, s. 789.

65 Ibidem, s. 136.

66 Zob. Bibliografia publikacji profesora Jerzego Chodorowskiego na stronie Uniwersytetu Wrocławskiego: Repozytorium Uniwersytetu Wrocławskiego http://www.repozytorium.uni.wroc.pl/ dlibra/ docmetadata $2 \mathrm{id}=64466 \&$ from $=\&$ dirids $=85 \& v e r \_i d=\& l p=1 \& Q \mathrm{I}=($ dostęp: $1.09 .2016 \mathrm{r}$. $)$. 
poświęconej W. Sameckiemu, wyraźne jest przeciwstawienie się poprawności politycznej w nauce z uwagi na skutki, jakie wywołuje w świadomości ludzi.

\section{Bibliografia}

Adamkiewicz-Drwiłło, H., Współczesna metodologia nauk ekonomicznych, Torun 2008.

Chodorowski J., Adam Smith (1723-1790), Wrocław 1980.

Chodorowski J., Adam Smith (1723-1790), życie i dzieło autora „Badań nad natura i przyczynami bogactwa narodów", Wrocław 2002.

Chodorowski J., Definicje w systemach ekonomicznych, „Prace Wrocławskiego Towarzystwa Naukowego. Seria A" 1974, nr 163.

Chodorowski J., Niemiecka doktryna gospodarki wielkiego obszaru Grossraumwirtschaft 18001945, Wrocław 1972.

Chodorowski J., Osoba ludzka w doktrynie i praktyce europejskich wspólnot gospodarczych, Poznań 1990.

Chodorowski J., Rodowód ideowy Unii Europejskiej, Krzeszowice 2005.

Chodorowski J., Roman Rybarski (1887-1942), Wrocław 1997.

Chodorowski J., Wiesław Samecki (1927-2007). Jeden z wielu ekonomistów na śmierć zamilczonych. Zarys poglądów ekonomicznych, Krzeszowice 2011.

Czarnomski M. (rec.), J. Chodorowski, Niemiecka doktryna gospodarki wielkiego obszaru, „Zaranie Śląskie" 1974, nr I-III.

Davis N., Brexit to katastrofalny bład, jego koszt będzie ogromny, „Tygodnik Powszechny” nr 27 z 3 lipca $2016 \mathrm{r}$.

Ekonomia w Polsce po dominacji marksistowskiej. Studia i materiały, red. L. Skiba, Wrocław 1998.

Krzeptowski A., Kulisy wielkiej manipulacji (na marginesie ksiażki Jerzego Chodorowskiego), „Prawica Narodowa” wrzesień-październik 1990 r., nr 3.

Kulwicki E., (rec.), W. Samecki, Ryzyko i niepewność w działalności przedsiębiorstwa przemystowego, Warszawa 1967, „Ekonomista” 1968, nr 3.

Mazur Z., (rec.), J. Chodorowski, Osoba ludzka w doktrynie i praktyce europejskich wspólnot gospodarczych, Poznań 1990, Prace Instytutu Zachodniego nr 55, „Przegląd Zachodni” 1992, nr 1.

Mises von L., Ludzkie działania: traktat o ekonomii, Warszawa 2007.

Mojsiewicz Cz., (rec.), J. Chodorowski, Niemiecka doktryna gospodarki wielkiego obszaru, „Ruch Prawniczy, Ekonomiczny i Socjologiczny" 1974 nr I.

Puchalski J., Typy uniwersalizmu światowego, „Demokracja Polska” z 16-31 grudnia 1993 r.

Samecki, W., Centralny Okręg Przemystowy 1936-1939: wstępna faza programu uprzemystowienia Polski, Wrocław 1998.

Samecki W., Gospodarowanie za pomoca planowania, Wrocław 1980.

Samecki W., Gospodarowanie za pomoca planowania: analiza krytyczna, Wrocław 2000.

Samecki W., Prolegomena do teorii ekonomii, Wrocław 1998.

Samecki W., Ryzyko i niepewność w działalności przedsiębiorstwa przemysłowego, Warszawa 1967.

Sutowicz P., J. Chodorowski, Roman Rybarski (1887-1942), Wrocław 1997, „Prawo” t. 250, „Życie i Myśl” 1998, nr 1.

Wolf-Powęska A., (rec.), J. Chodorowski, Niemiecka doktryna gospodarki wielkiego obszaru, „Studia Historica-Slavo-Germanica” 1975, vol. IV.

Studenckie Prace Prawnicze, Administratywistyczne i Ekonomiczne 19, 2016

(C) for this edition by CNS 


\section{Jerzy Chodorowski - economics theorist and historian of economic thought}

\section{Summary}

The scientific work of Jerzy Chodorowski does not leave readers indifferent to the issues raised in them. The perception of data problems, their presentation, the indication of the effects that cause certain phenomena or activities may raise an objection, admiration or approval. Different reactions can provide the opinions contained in the cited reviews. What does not raise any doubts, however, is the solidity, consistency and perseverance in searching for truth as well as author's extraodrinary diligence.

From monographs devoted to scientists-economists we are spoken to by persons whom we get to know as people with specific characteristics, beliefs, attitudes and scientific achievements. J. Chodorowski discreetly indicates the relationship between the personality of the scientist and his scientific works. We can be sure that everything that is written about each scientist was fairly and honestly researched and documented. In the last monograph devoted to W. Samecki there is a clear opposition to political correctness in science because of the effects it has on human consciousness. 